\title{
STRATEGI PEMASARAN Dengan METODE SWOT Dalam PERSAINGAN HARGA TIKET MASKAPAI PENERBANGAN
}

Oleh:

\author{
Irna Kumala \\ Program Studi Pendidikan Ekonomi \\ Fakultas Ilmu Pendidikan dan Pengetahuan Sosial \\ Universitas Indraprasta PGRI \\ Email: \\ irnakumala@yahoo.com
}

\begin{abstract}
ABSTRAK
Dalam penjualan tiket terdapat persaingan yang ketat antar maskapai sehingga dibutuhkan strategi pemasaran yang mampu membuat maskapai bertahan. Masalah yang dibahas mengenai strategi yang dijalankan maskapai Royal Brunei Airlines sebagai objek penelitian dalam menghadapi persaingan harga tiket. Penelitian ini bertujuan untuk mengetahui strategi yang dijalankan Royal Brunei Airlines dalam menghadapi persaingan harga tiket. Metode penelitian dilakukan dengan observasi, wawancara, kuesioner kemudian diolah menggunakan SWOT analysis. Berdasarkan analisis posisi perusahaan dari tabel IFAS dan EFAS, faktor internal sebesar 2,685 dan faktor eksternal sebesar 1,08. Maskapai ini mempunyai posisi menguntungkan pada kuadran 1, strategi agresif diterapkan karena memiliki kekuatan dan peluang yang positif. Berdasarkan matriks SWOT, strategi yang dapat diambil adalah strategi SO, yaitu memanfaatkan harga yang sangat kompetitif dan peraturan tiket yang fleksibel serta tetap menjaga hubungan baik dengan travel agent yang sudah loyal agar tidak berpaling. Dengan kondisi stabilitas ekonomi yang cukup baik di Indonesia, kegiatan Royal Brunei Airlines dalam menjual tiketnya tidak terganggu. Berdasarkan matriks Internal-Eksternal, posisi Royal Brunei Airlines berada pada kotak IV dengan total strategis internal sebesar 3,185 dan total strategis eksternal sebesar 2,68. Strategi stabilitas dapat diterapkan dengan membangun jaringan informasi yang lebih luas agar brand images Royal Brunei Airlines dapat lebih dikenal oleh masyarakat.
\end{abstract}

Kata kunci: maskapai penerbangan, strategi pemasaran, persaingan harga tiket, SWOT analysis. 


\section{A. PENDAHULUAN}

Strategi sangat diperlukan untuk menghadapi persaingan yang ada dalam lingkungan usaha dan untuk mempertahankan pangsa pasarnya. Melihat dan memahami dunia dari sudut pandang lain telah menjadi syarat mutlak agar dapat terus bertahan dalam suatu bisnis khususnya dalam dunia penerbangan. Fondasi manajemen strategis terletak pada kemampuan seorang manajer dalam memahami pesaing, pasar, harga, pemasok, distributor, regulasi Pemerintah, kreditor, pemegang saham, dan pelanggan. Royal Brunei Airlines yang selanjutnya disebut RBA ini pun mempunyai rencana-rencana strategis yang berisikan sasaran yang ingin dicapai di masa yang akan datang.

Hampir semua aspek dalam sistem penjualan jasa penerbangan menjadi sangat penting dalam mendukung kelancaran kegiatan operasional pada suatu rute. Contohnya adalah pada salah satu rute paling favorit yaitu Jakarta-Jeddah. Jeddah sendiri terkenal sebagai kota tujuan pengiriman Tenaga Kerja Indonesia (TKI) dengan tidak terlepas segala kontroversi dan kasus-kasus yang dialami oleh TKI di Jeddah. Namun, walaupun seperti itu, rute ini masih menjadi primadona. Hal ini dilihat sebagai peluang yang baik bagi beberapa maskapai yang mempunyai rute ini untuk terus memanfaatkan ataupun mengembangkan tingkat penjualannya pada rute ini. RBA pun menyadari bahwa walaupun ia bukan flag carrier negara Arab, namun ia masih bisa memanfaatkan kesempatan ini untuk ikut bersaing.

Dengan ramainya para pemain pada rute ini, pelayanan yang tak bercela menjadi harga mati dalam merebut market share sebesar-besarnya. Harga yang menarik, frekuensi penerbangan per minggu, konfigurasi seat pesawat, keramahan awak kabin, pelayanan ground handling, on time performance, pelayanan saat transit hingga pelayanan pasca penerbangan menjadi indikator jasa yang dapat dijual secara maksimal oleh setiap maskapai penerbangan yang berkompetisi pada rute ini.

Banyaknya tantangan seperti diatas, memacu RBA untuk merumuskan strateginya dalam menghadapi persaingan harga tiket rute Jakarta - Jeddah yang bersegmentasi pada pengangkutan Tenaga Kerja Indonesia (TKI). Dalam hal ini, RBA harus mengetahui secara jelas dan rinci mengenai kekuatan, dan kelemahan RBA, serta peluang maupun ancaman yang akan dihadapi. RBA pun dirasa sangat perlu mengidentifikasi strategi sebelumnya sebagai pedoman dalam menjalankan strategi berikutnya.

Sebagai suatu penelitian, hasil penelitian ini diharapkan dapat memberikan manfaat, yaitu memberikan masukan dan pertimbangan yang mungkin bermanfaat bagi perusahaan agar dapat meningkatkan produktivitasnya dalam angkutan Tenaga Kerja Indonesia (TKI), serta bisa menjadi salah satu rujukan penelitian lebih lanjut dengan ruang lingkup yang lebih luas. 


\section{B. KAJIAN PUSTAKA}

\section{Manajemen Strategi}

Menurut (David, 2006), manajemen strategis dapat didefinisikan sebagai: "seni dan pengetahuan dalam merumuskan, mengimplementasikan, serta mengevaluasi keputusan-keputusan lintas-fungsional yang memampukan sebuah organisasi mencapai tujuannya". Sedangkan menurut (Pearce \& Robinson, 2008), manajemen strategis adalah "Suatu set keputusan dan tindakan yang menghasilkan formulasi dan implementasi rencana yang dirancang untuk meraih tujuan suatu perusahaan".

Berdasarkan uraian diatas dapat disimpulkan bahwa manajemen strategi adalah suatu upaya dalam meningkatkan potensi perusahaan dan meraih peluang bisnis sebesar-besarnya melalui berbagai formulasi untuk mencapai misi yang telah ditentukan oleh organisasi tersebut sebelumnya.

Proses manajemen strategis menurut (Pearce \& Robinson, 2008), bahwa "Proses untuk merumuskan dan mengarahkan aktivitas manajemen strategis bervariasi antarbisnis. Para perencana terkemuka telah mengembangkan proses yang lebih rinci dibandingkan para perencana yang tidak begitu formal dari perusahaan-perusahaan dengan ukuran serupa."

Bisnis kecil yang mengandalkan keahlian penyusunan strategi dan waktu yang terbatas dari seorang pengusaha umumnya memperlihatkan lebih banyak keprihatinan perencanaan yang mendasar dibandingkan perusahaan yang lebih besar pada industri yang sama. Dapat dipahami bahwa perusahaan dengan banyak produk, pasar, atau teknologi cenderung menggunakan sistem manajemen strategis yang lebih rumit. Namun, meskipun terdapat perbedaan dalam rincian dan tingkat formalisasi, komponen-komponen dasar dari model yang digunakan untuk menganalisis operasi manajemen strategis pada umumnya sangat serupa.

\section{Peluang dan Ancaman Eksternal}

Peluang dan ancaman eksternal menunjuk pada berbagai tren kejadian ekonomi, sosial, budaya, demografis, lingkungan hidup, politik, hukum, pemerintahan, teknologi, dan kompetitif yang dapat secara signifikan menguntungkan atau merugikan suatu organisasi di masa yang akan datang. Sebagian besar peluang dan ancaman berada di luar kendali satu organisasi. Peluang dan ancaman yang lain bisa jadi meliputi munculnya aturan perundangundangan yang baru, introduksi produk baru oleh pesaing, bencana nasional, atau penurunan nilai dolar. Dalam manajemen strategis, perusahaan perlu merumuskan berbagai strategi untuk mengambil keuntungan dari peluang eksternal dan menghindari atau meminimalkan dampak ancaman eksternal.

\section{Kekuatan dan Kelemahan Internal}

Kekuatan dan kelemahan internal merupakan aktivitas terkontrol suatu organisasi yang mampu dijalankan dengan sangat baik atau buruk. Mereka muncul dalam manajemen, pemasaran, keuangan atau akuntansi, produksi atau operasi, penelitian dan pengembangan, dan aktivitas sistem informasi manajemen suatu bisnis. Mengidentifikasi serta mengevaluasi kekuatan dan kelemahan 
organisasional dalam wilayah-wilayah fungsional suatu bisnis merupakan aktivitas manajemen strategis yang esensial. Organisasi berjuang untuk menjalankan strategi yang mampu menggandakan kekuatan internal sekaligus meniadakan kelemahan internal.

\section{Strategi}

Strategi adalah sarana bersama dengan tujuan jangka panjang yang hendak dicapai. Strategi bisnis mencakup ekspansi geografis, diversifikasi, akuisisi, pengembangan produk, penetrasi pasar, pengetatan, divestasi, likuidasi, dan usaha patungan (joint venture). Strategi adalah aksi potensial yang membutuhkan keputusan manajemen puncak dan sumber daya perusahaan dalam jumlah yang besar. Selain itu, strategi mempengaruhi perkembangan jangka panjang perusahaan, biasanya untuk lima tahun ke depan, dan karenanya berorientasi ke masa yang akan datang.

Menurut (Wen \& Yeh, 2010), "Menghadapi lingkungan yang semakin kompetitif, maskapai penerbangan harus memposisikan merek mereka dalam benak para penumpang untuk mendapatkan keuntungan kompetitif." Perbedaan layanan adalah unsur penting untuk menentukan kemenangan di pasar. Studi ini mengidentifikasi posisi relatif dari maskapai penerbangan berdasarkan pemeriksaan kinerja pada delapan belas perusahaan penerbangan dalam hal atribut layanan. Dengan menggunakan data yang dikumpulkan dari penumpang Taiwan Airways yang telah terbang ke Tokyo dan Singapura, penelitian ini menggunakan dua metode statistik multivariasi, MDS dan CA, untuk membuat sebuah peta perseptual. Studi ini meneliti mengenai tingkat kekompetitifan, kekuatan kunci, dan kelemahan utama dari masing-masing penerbangan.

Persepsi penumpang dari perusahaan penerbangan secara substansial berbeda di seluruh rute udara, sehingga persaingan antar perusahaan penerbangan bervariasi dari rute satu ke rute lainnya. Ini menyoroti pentingnya posisi rute berdasarkan posisi. Setiap perusahaan penerbangan harus mengalokasikan sumber daya pemasaran untuk memaksimalkan keuntungan relatif terhadap potensi pesaing dalam setiap rute. Keterbatasan utama dari penelitian ini adalah bahwa hanya dua rute penerbangan internasional dipilih untuk studi empiris. Karena rute penumpang internasional udara cenderung memiliki keragaman profil dan karakteristik pasar.

Hasil analisis korespondensi ganda bisa membantu perusahaan penerbangan untuk menambah wawasan mengenai pesaing, jasa, dan penumpang. Selain itu, permintaan perjalanan bisa bervariasi antara penumpang penerbangan. Analisis segmentasi akan membuat lebih mudah bagi perusahaan penerbangan untuk menawarkan layanan yang tepat dan untuk menargetkan pasar inti. Penelitian di masa depan mungkin melakukan analisis segmentasi, pertama untuk pasar perjalanan udara internasional, dan kemudian posisi pada setiap segmen, mengidentifikasi posisi komparatif perusahaan penerbangan dan atribut layanan mereka. Penelitian segmentasi pertama dengan membagi menjadi beberapa segmen agar dapat mengembangkan pemasaran dan strategi operasional yang lebih efektif. 
Berkaitan dengan penelitian tersebut yang memakai metode MDS dan CA, dalam penelitian ini, peneliti menggunakan metode SWOT yang sama-sama mengkaji mengenai kekuatan, kelemahan, peluang, serta ancaman yang ada pada perusahaan. Penelitian ini digunakan untuk mengetahui posisi perusahaan saat ini dan mempersiapkan strategi yang tepat untuk menghadapi persaingan antar maskapai penerbangan.

\section{Manajemen Pemasaran}

Menurut (Kotler \& Keller, Manajemen Pemasaran, 2008), manajemen pemasaran adalah "Seni dan ilmu memilih pasar sasaran, meraih, mempertahankan serta menumbuhkan pelanggan dengan menciptakan, menghantarkan, dan mengkomunikasikan nilai pelanggan yang unggul".

Jadi, manajemen pemasaran dapat diartikan sebagai suatu rangkaian langkah-langkah dalam menentukan pasar, mendapatkan pasar, mengembangkan pasar, dan mengomunikasikan nilai pelanggan untuk meningkatkan keefektifitasan dan keefektifan kegiatan pemasaran yang unggul oleh individu atau perusahaan.

Pemasar adalah seseorang yang mencari respon, perhatian, pembelian, dukungan, sumbangandari pihak lain yang disebut prospek. Ada delapan permintaan yang mungkin terjadi, hal ini semua diungkapkan (Kotler \& Keller, Manajemen Pemasaran, 2008):

1. Permintaan negatif. Konsumen mungkin tidak menyukai produk dan mungkin bahkan berusaha menghindarinya.

2. Permintaan yang tidak ada. Konsumen mungkin tidak sadar atau akan tidak tertarik pada produk.

3. Permintaan laten. Konsumen mungkin memiliki suatu kebutuhan yang kuat yang tidak bisa dipenuhi produk yang ada.

4. Permintaan yang menurun. Konsumen mulai jarang membeli produk atau tidak membeli sama sekali.

5. Permintaan tidak teratur. Konsumen membeli secara musiman, bulanan, mingguan, harian, atau bahkan dalam hitungan jam.

6. Permintaan penuh. Konsumen membeli semua produk yang dilempar ke pasar.

7. Permintaan berlimpah. Konsumen mau membeli produk lebih banyak daripada produk yang ada.

8. Permintaan tak sehat. Konsumen mungkin tertarik pada produk yang memiliki konsekuensi sosial yang tidak diinginkan.

\section{Bauran Pemasaran}

Menurut (Kotler \& Armstrong, Prinsip-Prinisp Pemasaran, 2006), bauran pemasaran adalah "Perangkat alat pemasaran taktis yang dapat dikendalikan, yang dipadukan oleh perusahaan untuk menghasilkan respon yang diinginkan dalam pasar sasaran". Bauran pemasaran ini terdiri dari:

a. Produk (Product) berarti kombinasi "barang dan jasa" yang ditawarkan oleh perusahaan kepada pasar sasaran. 
b. Harga (Price) adalah jumlah uang yang harus dibayar oleh pelanggan untuk memperoleh produk tadi.

c. Distribusi (Place) termasuk aktivitas perusahaan untuk membuat produk tersedia bagi konsumen sasaran.

d. Promosi (Promotion) yaitu aktivitas yang mengkomunikasikan keunggulan produk dan membujuk pelanggan sasaran untuk membelinya.

e. Manusia (People) berfungsi sebagai penyedia jasa yang sangat mempengaruhi kualitas jasa yang diberikan.

f. Proses (Process) merupakan gabungan semua aktifitas yang terdiri atas prosedur, jadwal kerja, mekanisme, aktifitas, dan hal rutin dimana jasa dihasilkan dan disampaikan kepada konsumen.

g. Physical Evidence adalah hal ini terkait dengan penampilan yang berbeda dengan memberikan pelayanan, baik operasional maupun administratif, yang ramah dan nyaman serta janji yang terjamin.

\section{Segmentasi Pasar}

Menurut (Laksana, 2008), "Pemasaran sasaran dilakukan oleh pemasar melalui tiga langkah utama yaitu:

a. Market segmentation atau segmentasi pasar yaitu mengidentifikasi dan memilih-milih kelompok pembeli yang berbeda-beda yang mungkin meminta produk dan atau bauran pemasaran tersendiri.

b. Market targetting atau pasar sasaran yaiu memilih satu atau lebih segmen pasar untuk dimasuki.

c. Market positioning atau penetapan posisi pasar yaitu membentuk dan mengkomunikasikan manfaat utama yang membedakan produk perusahaan dengan produk lain di pasar.

Setelah mengevaluasi segmen-segmen yang berbeda, perusahaan dapat mempertimbangkan lima pola pemilihan pasar sasaran, yaitu:

\section{a. Konsentrasi Segmen Tunggal}

Perusahaan bisa memilih sebuah segmen tunggal. Melalui pemasaran yang terkonsentrasi, perusahaan mendapatkan pengetahuan yang kuat tentang kebutuhan segmen dan memilih posisi pasar yang kuat di segmen tersebut. Lebih jauh, perusahaan menikmati operasi yang ekonomis melalui spesialisasi produksi, distribusi, dan promosinya. Jika ia menjadi pemimpin di segmen tersebut, perusahaan dapat menghasilkan tingkat pengembalian investasi yang tinggi. Ketika segolongan konsumen mendadak berhenti membeli suatu jenis produk, maka penghasilan perusahaan yang memproduksi produk tersebut menurun tajam. Atau seorang pesaing mungkin menyerang segmen tersebut. Dengan alasan itu, banyak perusahaan lebih suka beroperasi di lebih dari satu segmen.

\section{b. Spesialisasi efektif}

Dalam hal ini, perusahaan memilih sejmlah segmen, secara objektif masingmasing segmen menarik dan memadai. Mungkin terdapat sedikit atau tidak ada sinergi diantara segmen-segmen tersebut, namun masing-masing berpotensi 
sebagai penghasil uang. Strategi cakupan multi-segmen itu memiliki keuntungan pendiversifikasian resiko perusahaan.

c. Spesialisasi produk

Dalam hal ini, perusahaan berkonsentrasi dalam menghasilkan produk tertentu yang dijual ke beberapa segmen. Melalui strategi spesialisasi produk, perusahaan membangun reputasi yang kuat di bidang produk tertentu. Resiko yang tidak menguntungkan adalah bahwa produk tertentu tersebut mungkin digantikan oleh produk yang sejenis yang lebih canggih.

\section{d. Spesialisasi pasar}

Dalam hal ini, perusahaan berkonsentrasi untuk melayani berbagai kebutuhan dari suatu kelompok pelanggan tertentu. Perusahaan mendapatka reputasi yang kuat dengan mengkhususkan diri dalam melayani kelompok pelanggan itu dan menjadi saluran pemasaran bagi semua produk baru yang mungkin digunakan oleh kelompok pelanggan ini. Resiko yang tidak menguntungkan adalah bahwa kelompok pelanggan itu mungkin harus memotong anggaran mereka.

\section{e. Cakupan Seluruh Pasar}

Dalam hal ini perusahaan berusaha melayani seluruh kelompok pelanggan dengan menyediakan semua produk yang mungkin mereka butuhkan. Hanya perusahaan yang sangat besar yang dapat melaksanakan strategi cakupan pasar. Perusahaan besar dapat mencakup seluruh pasar dengan dua cara umum, yaitu melalui pemasaran yang tidak terdiferensiasi atau pemasaran yang terdiferensiasi. Dalam pemasaran yang tidak terdiferensiasi, perusahaan mengabaikan perbedaan segmen pasar dan meraih seluruh pasar dengan satu tawaran pasar. Ia memusatkan perhatian kepada kebutuhan pembeli yang bersifat dasar dan bukannya perbedaan diantara pembeli. Ia merancang suatu produk atau suatu program pemasaran yang akan menarik jumlah pembeli terbesar. Ia menggantungkan diri kepada distribusi dan pengiklanan masal. Ia berusaha memberikan citra produk yang superior ke dalam benak orang-orang. Pemasaran yang terdiferensiasi sering dipandang sebagai rekan pemasaran bagi stadarisasi dan produk masal di perusahaan manufaktur. Lini produk yang sempit menurunkan biaya litbang, produksi, persediaan, transportasi, riset pemasaran, periklanan, dan manajemen produk. Program periklanan yang tidak terdiferensiasi menurunkan biaya periklanan. Perusahaan dapat mengubah biayanya yang lebih rendah menjadi harga yang lebih rendah sehingga dapat menang di segmen pasar yang peka terhadap harga. Dalam perusahaan yang terdiferensiasi, perusahaan beroperasi di beberapa segmen pasar yang merancang program yang berbeda bagi masing-masing segmen.

\section{Karakteristik Industri Penerbangan}

Karakteristik industri penerbangan pada umumnya padat teknologi, padat karya, padat modal, dan padat aturan. Sebagai moda yang paling modern, maka 
industri penerbangan pun memiliki karakteristik tersebut. Menurut (Madjid, 2009), karakteristik tersebut dapat dijabarkan sebagai berikut:

\section{Padat Teknologi (Highly Technology Intensive)}

Teknologi merupakan sebuah gabungan dari sumber daya yang berwujud (tangible resources) dan pengetahuan yang tidak berwujud (intangible knowledge) yang secara bersama-sama memampukan suatu perusahaan penerbangan untuk mengubah masukan (input) menjadi keluaran (output) dan hasil (outcomes). Bisnis penerbangan sangat peka terhadap teknologi maupun perubahan teknologi itu sendiri, sehingga termasuk dalam kategori industri yang berbiaya sangat tinggi.

Kemajuan teknologi dapat memberikan peluang bagi industri penerbangan. Oleh karena teknologi dapat menciptakan keuntungan bersaing (competitive advantage) dengan meningkatkan faktor produktivitas, yaitu dengan asumsi harga tetap, pesawat yang hemat bahan bakar akan meningkatkan produktivitas dari setiap Rupiah yang dibayarkan untuk bahan bakar; pesawat yang lebih besar akan meningkatkan produktivitas dari setiap Rupiah yang akan dikeluarkan untuk biaya operasional; otomatisasi di kokpit dan pelayanan darat (ground handling) akan meningkatkan produktivitas dari setiap Rupiah yang dikeluarkan untuk tenaga kerja.

Teknologi pemasaran digunakan agar para pelanggan dapat secara langsung masuk ke dalam sistem pelayanan dari suatu perusahaan penerbangan, di mana fokus dari teknologi ini adalah untuk mendapatkan data pasar dan mengubah data tersebut menjadi informasi yang berguna bagi perusahaan penerbangan.

\section{Padat Karya (Highly Labor Intensive)}

Industri jasa penerbangan merupakan "people-based service industry" sehingga sumber daya manusia merupakan subjek atau faktor yang sangat berperan dalam mendukung terciptanya pelayanan atau produk yang berkualitas bagi para pengguna jasa. Industri penerbangan merupakan bisnis yang padat karya, oleh karena membutuhkan sumber daya manusia dalam jumlah yang besar, tergantung kepada besar dan kecil perusahaan penerbangan, banyaknya jumlah armada pesawat serta jaringan rute penerbangannya.

Dibandingkan dengan industri lainnya, sumber daya manusia dalam industri penerbangan merupakan tenaga kerja yang memiliki keterampilan tinggi (highly skilled labor) dan memiliki derajat tanggung jawab yang tinggi pula (high degree of responsibilities). Sifat alamiah dari bisnis penerbangan menuntut waktu operasional 24 jam kerja setiap hari sepanjang tahun dan tersebarnya tenaga kerja di seluruh penjuru negeri bahkan seluruh dunia.

\section{Padat Hubungan Antar Manusia (Human Relation Intensive)}

Keberhasilan dan kemajuan perusahaan penerbangan adalah sangat ditentukan oleh hubungan antar manusia yang ada di dalam perusahaan, baik itu hubungan antara perusahaan dengan karyawannya, perusahaan dengan para pelanggannya maupun karyawan perusahaan dengan pelanggan perusahaan dan juga antar sesama karyawan. Semakin baik hubungan ini terjalin, maka semakin 
baik pula hasil dan kinerja yang akan diperoleh oleh semua pihak, baik itu bagi perusahaan penerbangan, karyawannya, dan pelanggannya.

\section{Padat Modal (Highly Capital Intensive)}

Perusahaan penerbangan membutuhkan berbagai macam peralatan, perlengkapan, dan berbagai fasilitas yang mahal harganya. Mulai dari pesawat terbang, simulator pesawat, sampai dengan hanggar perawatan pesawat, yang merupakan bagian dari teknologi produksi. Selain itu, dalam hal pemanfaatan teknologi pemasaran, bila perusahaan penerbangan menggunakan sistem reservasi menggunakan komputer serta sistem manajemen pendapatan akan memerlukan biaya investasi yang cukup tinggi. Sehingga pada akhirnya, industri penerbangan merupakan bisnis yang membutuhkan modal besar atau padat modal.

\section{Padat Aturan (Strictly Regulation)}

Dalam bisnis penerbangan, keselamatan merupakan prioritas utama dan pertama yang menentukan maju atau mundurnya suatu perusahaan penerbangan. Oleh karena itu, hal ini berkaitan langsung dengan nyawa manusia. Untuk menjamin dan memastikan terciptanya dan tercapainya keselamatan penerbangan, ditambah keamanan dan kenyamanan penerbangan, maka dibuatlah aturan main yang wajib dipatuhi dan dijalankan oleh seluruh perusahaan penerbangan di dunia. Badan dunia yang mengatur penerbangan sipil tersebut adalah International Civil Aviation Organization (ICAO) yang beranggotakan 190 negara yang disebut contracting states. ICAO mengeluarkan peraturan keselamatan penerbangan sipil atau Civil Aviation Safety Regulation (CASR) yang merupakan standar rekomendasi praktis dan prosedur internasional yang meliputi bidang-bidang teknis penerbangan.

Terdapat juga organisasi penerbangan dunia yang bernama International Air Transport Association (IATA), yang mengembangkan standar dan prosedur yang mendukung operasional penerbangan internasional secara khusus bagi anggotanya. Standar dan prosedur internasional tersebut juga diterapkan oleh beberapa perusahaan penerbangan nonanggota IATA. Selain itu, perusahaan atau pabrik pembuat pesawat terbang, pada saat meluncurkan dan menjual produk pesawatnya kepada perusahaan penerbangan, selalu melengkapi pesawatnya dengan Aircraft Operating Manuals (AOM) atau petunjuk pengoperasian pesawat. AOM tersebut harus dipatuhi dan dilaksanakan oleh perusahaan penerbangan yang mengoperasikan pesawat tersebut, termasuk perawatannya sehingga jaminan keselamatan penerbangan dapat tercapai.

Menurut (Mastra, 2008), "kajian daya saing perusahaan angkutan udara nasional Indonesia menemukan dua hal pokok. Pertama, kekuatan daya saing perusahaan sangat bervariasi. Ada yang sangat kuat, sedang, dan yang terbanyak yang sangat lemah secara relatif diantara enam perusahaan yang dijadikan sampel. Kedua, perbandingan kekuatan daya saing antar perusahaan sangat nyata perbedaannya. Dalam arti, kondisi ini menunjukkan bahwa persaingan sangat timpang atau sama dengan tidak ada persaingan. 


\section{METODE PENELITIAN}

Penelitian yang dilakukan bertujuan untuk memberikan masukan maupun pertimbangan kepada RBA dalam menyusun strategi persaingan harga tiket pada segmentasi angkutan Tenaga Kerja Indonesia (TKI) dan juga diharapkan dapat meningkatkan produktivitas angkutan tenaga kerja Indonesia. Penelitian ini dilakukan di Royal Brunei Airlines cabang Bandara Soekarno Hatta, Cengkareng, sebagai salah satu kantor perwakilan RBA di Indonesia. Penyebaran kuesioner wawancara, dan studi dokumen dilakukan di dua tempat yaitu di kantor pusat RBA dan kantor cabang RBA, Cengkareng.

Penelitian ini dilakukan dengan menggunakan analisis SWOT (Rangkuti, 2006) karena dirasa sesuai dengan tujuan yaitu untuk memformulasi sebuah strategi. Dalam analisis SWOT ini, dilakukan identifikasi berbagai faktor yaitu kekuatan, kelemahan, peluang, dan ancaman perusahaan. Setiap identifikasi ini dituangkan dalam suatu matriks penentuan posisi perusahaan yang terbagi menjadi empat kuadran. Masing-masing kuadran tersebut adalah kuadran I yaitu posisi dalam mendukung strategi agresif, kuadran II adalah posisi mendukung strategi diversifikasi, kuadran III yang mendukung strategi putar haluan, dan kuadran IV yang mendukung strategi defensif.

Namun, sebelum matriks SWOT teridentifikasi, kita perlu mengetahui terlebih dahulu mengenai faktor riil internal maupun eksternalnya. Penentuan faktor-faktor ini dilakukan dengan cara melakukan wawancara terhadap pihakpihak pemangku jabatan yang akan mengambil suatu kebijakan nantinya. Faktorfaktor kekuatan dan kelemahan dimasukkan ke dalam tabel IFAS (matrik faktor strategi internal) untuk dihitung bobot, rating, dan skornya. Selanjutnya, hal tersebut juga dilakukan terhadap faktor-faktor peluang dan ancamannya yang dimasukkan ke dalam tabel EFAS (matrik faktor strategi eksternal).

Selanjutnya, untuk memperoleh strategi bisnis yang lebih detail lagi, dapat kita gunakan matrik Internal Eksternal (IE). Parameter yang digunakan meliputi parameter kekuatan internal perusahaan dan pengaruh eksternal yang dihadapi. Berbeda dengan matrik SWOT, matrik IE ini terbagi menjadi 9 kuadran yaitu strategi pertumbuhan, penciutan, stabilitas, maupun likuidasi. Hasil pengolahan data dari wawancara dan penyebaran angket dianalisis secara induktif berdasarkan aspek-aspek masalah penelitian dan secara deduktif mengacu pada teori yang dirujuk. Hasil pembahasan tersebut pun selanjutnya dijadikan bahan untuk menarik simpulan serta merumuskan saran penelitian.

\section{HASIL DAN PEMBAHASAN}

Faktor internal persaingan harga tiket rute Jakarta-Jeddah pada segmentasi TKI:

1. Kekuatan:

a) Harga yang kompetitif.

b) Memiliki program diskon yang menarik.

c) Memiliki kinerja ketepatan waktu yang baik.

d) Memiliki armada pesawat dengan performansi yang baik. 
e) Memiliki penerbangan hanya dengan sekali transit.

f) Memiliki jadwal penerbangan dengan tingkat kepastian yang tinggi.

g) Peraturan tiket yang lebih fleksibel.

2. Kelemahan:

a) Tidak ada penerbangan langsung ke Jeddah.

b) Frekuensi penerbangan dalam 1 hari sangat terbatas.

c) Brand images yang masih rendah untuk pasar Indonesia.

Terdapat beberapa faktor internal persaingan harga tiket rute Jakarta Jeddah pada segmentasi TKI. Berdasarkan poin harga yang kompetitif, dalam hal ini RBA mendapatkan skor sebesar 0,60 yang selanjutnya poin ini menjadi poin terbesar dalam menyumbangkan total poin dalam segi kekuatan RBA yaitu sebesar 2,935. Sedangkan dalam segi kelemahannya, skor yang paling besar yaitu sebesar 0,12 didapat dari faktor kelemahan bahwa tidak adanya penerbangan langsung ke Jeddah. Skor total dalam segi kelemahan RBA didapati sebesar 0,25. Maka, dari faktor internal tersebut didapatkan skor faktor internal sebesar 2,685. TKI:

Faktor eksternal persaingan harga tiket rute Jakarta-Jeddah pada segmentasi

1. Peluang:

a) Permintaan akan Tenaga Kerja Indonesia (TKI) yang tinggi.

b) Keadaan perekonomian Indonesia yang cukup baik.

c) Hubungan Pemerintah Indonesia dan Saudi Arabia yang baik.

d) Memiliki dan terus dapat menjaga hubungan kerjasama yang baik dengan para Travel Agent.

2. Ancaman:

a) Munculnya pemain-pemain baru pada rute Jakarta-Jeddah.

b) Adanya airlines lain yang memiliki penerbangan langsung.

c) Citra yang kurang baik mengenai hubungan antara majikan dan para pekerja (TKI) di Jeddah.

d) Kondisi alam dan cuaca yang kurang baik di Indonesia dalam 2 tahun terakhir ini.

e) Minat orang Indonesia untuk bekerja di Jeddah telah berkurang.

f) Kenaikan harga fuel secara global.

Setelah kita ketahui faktor internal persaingan harga tiket rute JakartaJeddah pada segmentasi TKI, harus kita ketahui pula faktor eksternalnya. Berdasarkan poin hubungan Pemerintah Indonesia dan Saudia Arabia serta memiliki dan terus dapat menjaga hubungan kerjasama yang baik dengan para travel agent bersama-sama dalam hal ini RBA mendapatkan skor sebesar 0,56 yang selanjutnya kedua poin ini menjadi poin terbesar dalam menyumbangkan total poin dalam segi peluang RBA yaitu sebesar 1,88. Sedangkan dalam segi ancamannya, skor yang paling besar yaitu sebesar 0,16 yang didapat dari faktor ancaman yaitu citra yang kurang baik mengenai hubungan antara majikan dan 
para pekerja (TKI) di Jeddah serta kondisi alam dan cuaca yang kurang baik di Indonesia dalam 2 tahun terakhir. Skor total dalam segi ancaman RBA didapati sebesar 0,8. Maka, dari faktor eksternal tersebut didapatkan skor faktor eksternal sebesar 1,08 .

Strategi yang dijalankan Royal Brunei Airlines dalam menghadapi persaingan harga tiket pada rute Jakarta-Jeddah ditunjukkan melalui matriks dibawah ini, bahwa perusahaan berada pada kuadran I yaitu mendukung strategi agresif.

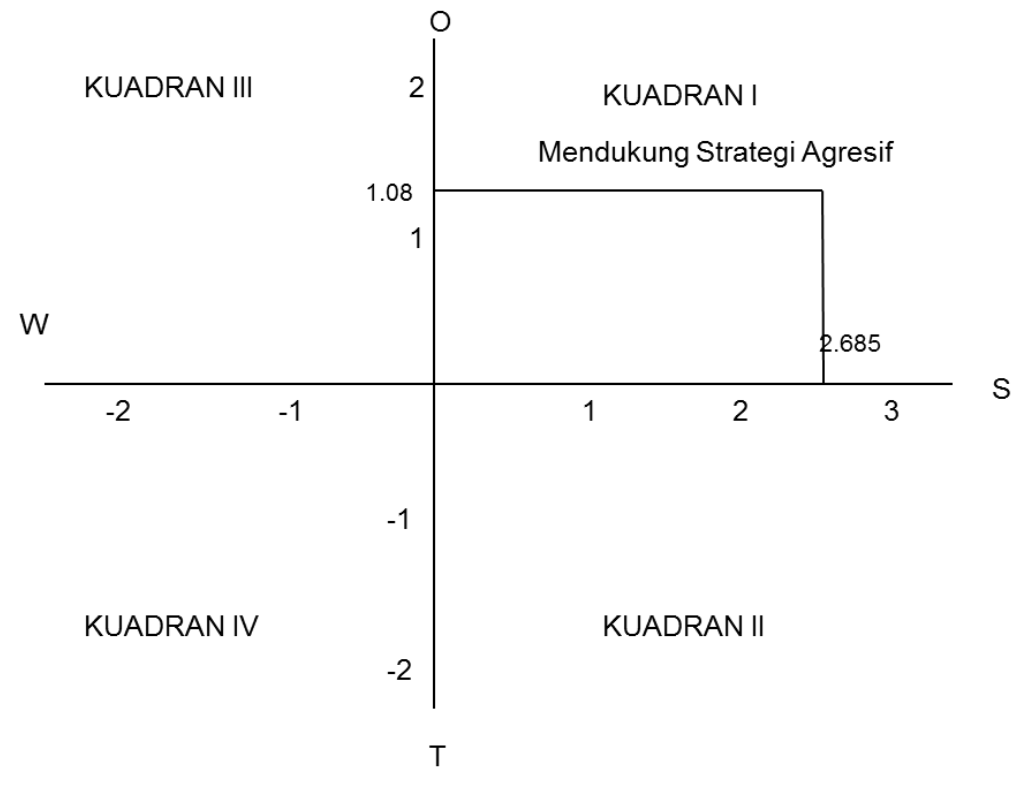

Gambar 1.

Matriks Penentuan Posisi Perusahaan

Keterangan Gambar:

Matriks Penentuan Posisi Perusahaan

- $\quad$ Faktor Internal $(X)=$ Sub total Kekuatan - Sub total Kelemahan

Faktor Internal $(X)=2,935-0,25=2,685$

- Faktor Eksternal $(\mathrm{Y})=$ Sub total Peluang - Sub total Ancaman

Faktor Eksternal $(Y)=1,88-0,8=1,08$

Sedangkan, untuk hasil matriks SWOT digambarkan dengan tabel dibawah ini. Terlihat bahwa dalam hal ini, perusahaan disarankan untuk memanfaatkan strategi SO (Strength Opportunity) yaitu strategi yang menitik beratkan kekuatan perusahaan itu sendiri tanpa mengabaikan peluang-peluang yang ada di sekitarnya. 
Tabel 1.

Matriks SWOT Royal Brunei Airlines

\begin{tabular}{|c|c|c|c|}
\hline & EFAS & $\begin{array}{l}\text { Strengths (Kekuatan) } \\
\text { 1. Harga yang kompetitifi } \\
\text { 2. Memiliki program diskon yang menarik } \\
\text { 3. Memiliki kinerja ketepatan waktu yang baik } \\
\text { 4. Memiliki armada pesawat dengan performansi yang } \\
\text { baik } \\
\text { 5. Memiliki penererbangan hanya dengan sekâli transit } \\
\text { 6. Memiliki jadwal penerbangan dengan tingkat } \\
\text { kepastian yang tinggi } \\
\text { 7. Peraturan tiket yang lebih fleksibel }\end{array}$ & \begin{tabular}{|ll}
\multicolumn{1}{|c}{ Weaknesses (Kelemahan) } \\
1. & Tidak ada penerbangan langsung ke Jeddah \\
2. & Frekuensi penerbangan dalam sehari sangat \\
terbatas \\
3. & Brandimages yang masih rendah untuk pasar \\
& Indonesia
\end{tabular} \\
\hline $\begin{array}{l}3 . \\
4 .\end{array}$ & $\begin{array}{l}\text { Opportunity (Peluang) } \\
\text { Permintaan akan tenaga kerja Indonesia yang } \\
\text { tinggi } \\
\text { Keadaann perekonomomiañ Indonesia yang cukup } \\
\text { baik } \\
\text { Hubunganin pemerintăh Indonesia dan Arab } \\
\text { Saudi yang baik } \\
\text { Memiliki dan terus dapat menjaga hubungan } \\
\text { kerjasama yang baik dengan para Travel Agent }\end{array}$ & $\begin{array}{l}\text { Strategi (SO) } \\
\text { 1. } \\
\text { Memanfaatkan harga yang sangat kompetitif dan } \\
\text { peraturan tiket yang lebih fleksibel agar dapat } \\
\text { menambah kerjasama yang baik dengant para travel } \\
\text { agent baru, dan tetap menjaga hubungan dengan } \\
\text { travel agent yang sudah loyal agar tidak berpaling. } \\
\text { 2. Dengan adanya stabilitas ekonomi yang cukup baik } \\
\text { di Indonesia, maka diharapkan kekuatan Royal } \\
\text { Brunei Airlines dalam menjual tiketnya secara } \\
\text { kompetitif tidak terganggu. }\end{array}$ & 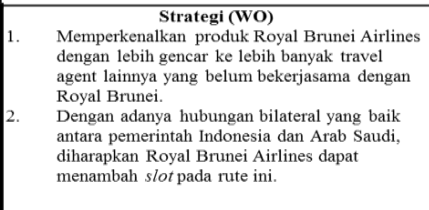 \\
\hline 3 & $\begin{array}{l}\text { Threaths (Ancaman) } \\
\text { Munculyya pemain-pemain baru pada rute } \\
\text { Jakarta Jeddah } \\
\text { Adanya airlines lain yang memiliki } \\
\text { penerbangan langsung } \\
\text { Citra yang kurang baik mengenai hubungan } \\
\text { antara majikan dan para pekerja (TKI) di } \\
\text { Jeddah } \\
\text { Kondisi alam dan cuaca yang kurang baik di } \\
\text { Indonesia dalam dua tahun terakhir ini } \\
\text { Minat orang Indonesia untuk bekerja di Jeddah } \\
\text { berkurang } \\
\text { Kenaikan harga fuel secara global }\end{array}$ & $\begin{array}{ll}\text { Strategi (ST) } \\
\text { 1. } & \text { Walaupun ada perusahaan penerbangan baru yang } \\
\text { muncul di rute ini, tetapi Royal Brunei Airlines } \\
\text { dapat menawarkan harga yang sangat kompetitif } \\
\text { kepada pelanggan. } \\
\text { 2. } & \text { Royal Brunei Airlines dapat mengatasi ancaman } \\
\text { terhadapa adanya airlines lain yang melayani rute } \\
\text { Jakarta--Jeddah pula dengan menawarkan jadwal } \\
\text { dengan tingkat kepastian yang tinggi dan } \\
\text { menawarkan diskon-diskon tertentu setiap } \\
\text { musimnya. }\end{array}$ & 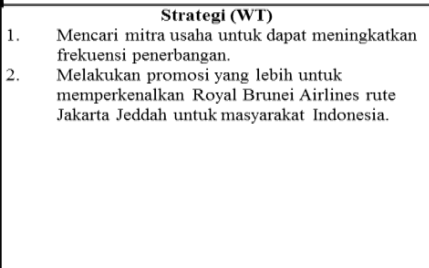 \\
\hline
\end{tabular}

Selain itu, dilihat dari matriks internal eksternalnya, Royal Brunei Airlines berada pada kuadran IV, dengan skor 2.68 yang menunjukkan strategi dalam mempertahankan kestabilitasannya. Matriks internal eksternal ditunjukkan seperti tabel dibawah.

Tabel 2.

Matriks Internal \& Eksternal Royal Brunei

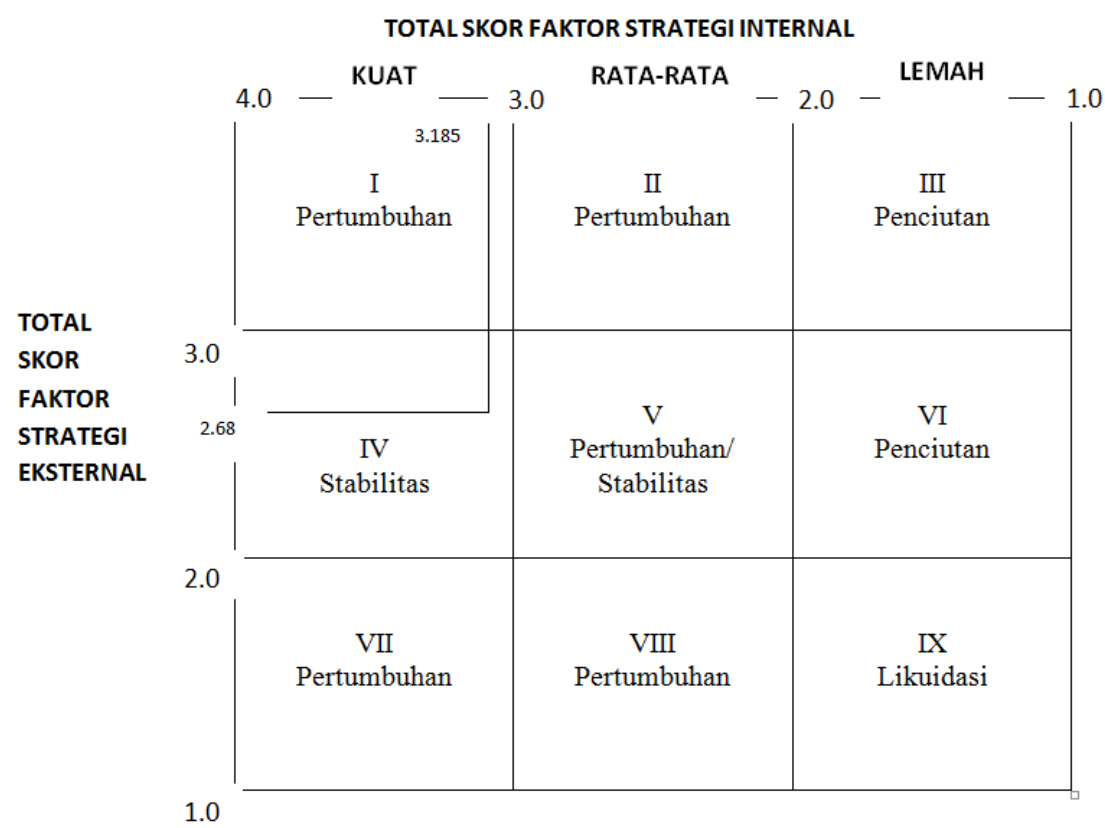




\section{E. SIMPULAN}

Berdasarkan pembahasan faktor internal yang terdiri dari kekuatan dan kelemahan yang dimiliki oleh Royal Brunei Airlines, maka kesimpulannya adalah sebagai berikut: 1) Harga yang kompetitif pada rute Jakarta-Jeddah adalah suatu keunggulan, 2) Program diskon yang menarik serta peraturan tiket yang lebih fleksibel, 3) Brand images yang masih lemah untuk masyarakat Indonesia dan frekuensi penerbangan yang masih terbatas.

Berdasarkan pembahasan faktor eksternal yang terdiri dari peluang dan ancaman yang dimiliki oleh Royal Brunei Airlines, maka kesimpulannya adalah sebagai berikut: 1) Indonesia yang terkenal sebagai Negara pemasok tenaga kerja terbanyak dan termurah menjadikan Indonesia tetap menjadi Negara yang paling diminati, 2) Hubungan yang baik antara Royal Brunei Airlines dan para travel agentnya membuat kegiatan perusahaan berjalan cukup lancar, 3) Munculnya pemain-pemain baru yang terbang secara langsung pada rute Jakarta Jeddah ini dinilai cukup mengancam, 4) Adanya berita-berita yang kurang baik mengenai perlakuan majikan terhadap para tenaga kerja di Arab Saudi, membuat tenaga kerja Indonesia yang akan dikirim merasa khawatir.

Berdasarkan evaluasi strategi yang telah dijalankan oleh Royal Brunei Airlines dalam menghadapi persaingan harga tiket, maka kesimpulannya adalah: 1) Pembuatan konsorsium ke agen-agen perjalanan masih menjadi strategi yang tepat, 2)Pembangunan pasar umroh dengan membuat pemberhentian dan pengkombinasian paket umroh dengan tujuan ASEAN dan Eropa masih tepat, 3) Penjualan tiket secara lebih agresif masih menjadi strategi yang tepat.

Berdasarkan analisis dan pembahasan faktor internal maupun eksternal yang dimiliki oleh Royal Brunei Airlines dalam rangka menghadapi persaingan harga tiket rute Jakarta-Jeddah, maka kesimpulannya adalah sebagai berikut: 1) Setelah dilakukan analisis posisi perusahaan, RBA berada pada kuadran I yang berarti bahwa RBA harus menerapkan strategi agresif, 2) Setelah dilakukan analisis SWOT, strategi yang sebaiknya diambil adalah SO (Strength Opportunity) yaitu dengan memanfaatkan harga yang sangat kompetitif, peraturan tiket yang lebih fleksibel, menjalin hubungan dengan baik maupun menambah travel agent baru. Serta memanfaatkan stabilitas ekonomi yang cukup baik di Indonesia dalam mengembangkan usahanya.

Berdasarkan matriks internal-eksternal, maka RBA dalam melakukan kegiatan penjualan tiket Jakarta-Jeddah berada di kotak IV yang menunjukkan bahwa strategi yang harus diambil adalah stabilitas.

Berdasarkan simpulan diatas, maka rekomendasi yang dapat penulis berikan adalah sebagai berikut:

1. Perusahaan sebaiknya tetap menjalin dan mempertahankan hubungan baik dengan para travel agent yang sering dan sudah lama bekerja sama dengan RBA dengan memberikan kemudahan-kemudahan pesanan tiket grup, pemberian prioritas, pemberian penghargaan berkala, pemberian insentif, dsb.

2. Perusahaan sebaiknya meningkatkan frekuensi penerbangan yang masih terbatas dengan menjalin kerjasama dengan perusahaan penerbangan lainnya rute Jakarta-Jeddah. 
3. Perusahaan sebaiknya membangun jaringan informasi yang lebih luas agar brand images RBA lebih kuat dan dapat dikenal lagi oleh masyarakat Indonesia.

\section{DAFTAR PUSTAKA}

David, F. R. (2006). Manajemen Strategi (12 ed., Vol. 1). Jakarta, DKI Jakarta, Indonesia: Salemba Empat.

Kotler, P., \& Keller, K. L. (2008). Manajemen Pemasaran (13 ed., Vol. 1). (B. Sabran, Penerj.) Jakarta, DKI Jakarta, Indonesia: Erlangga.

Laksana, F. (2008). Manajemen Pemasaran: Pendekatan Praktis. Yogyakarta.

Madjid, S. A. (2009). Customer Service dalam Bisnis Jasa Transportasi. Jakarta, DKI Jakarta, Indonesia: Rajawali Pers.

Pearce, J. A., \& Robinson, R. b. (2008). Manajemen Strategis: Formulasi, Implementasi, dan Pengendalian (10 ed., Vol. 1). Jakarta, DKI Jakarta, Indonesia: Salemba Empat.

Rangkuti, F. (2006). Analisis SWOT: Teknik Membedah Kasus Bisnis-Reorientasi Konsep Perencanaan Strategik untuk Menghadapi Abad 21. Jakarta, DKI Jakarta, Indonesia: Gramedia Pustaka Utama.

Wen, H., \& Yeh, Y. (2010). Positioning of International Air Passenger Carriers Using Multidimensional Scalling and Correspondence Analysis. The Journal of The American Society of Transportation and Logistics , 49 (1), 151-162. 